\title{
Energy Replenishment Diversification Under Marine Spatial Planning Connects Big Data, Artificial Intelligence, Internet of Things for Coastal Community Sustainability
}

Victor Te Cheng Liao ( $\nabla$ victortechengliao@gmail.com ) National Taiwan Ocean University

Original article

Keywords: Energy replenishment, energy diversification, integrated coastal zone management (ICZM), sustainable coastal community development (SCCD), marine spatial planning (MSP), ecological or biological significant area (EBSA)

Posted Date: June 29th, 2020

DOI: https://doi.org/10.21203/rs.3.rs-35727/v1

License: (a) (i) This work is licensed under a Creative Commons Attribution 4.0 International License. Read Full License 


\section{Abstract}

Background Controversial coal power plant restart and non-nuke policy were rejected by referendum in Taiwan on 24 Nov 2018. Outcomes affecting energy replenishment and undermining economic stability are criticized politicization because coal energy is detrimental but no nuke beneficial for the environment. These policies could be contradictory.

Problem No autonomous energy puts the country into extreme risk and is controlled by foreigners. Developing energy faces a traditional tradeoff between economic development and environmental protection.

Purpose The assumption an innovative energy diversification linking Big Data, artificial intelligence (Al), and the Internet of Things (IoT) is encouraged. The paper investigates upgrading liquified petroleum gas (LPG) to liquified natural gas (LNG) under marine spatial planning (MSP) for energy replenishment and creating an energy diversification framework through integrated coastal zone management (ICZM) linking Big Data, loT, Al whether are supported.

Results Online sampling investigation results, enhancing LPG to LNG at the ecologically biologically significant area (EBSA) under MSP was less encouraged but linking Big Data, loT, Al innovation through ICZM was overwhelmingly supported and consistent with goalkeepers interview. Research finding gender, the environment, age revealed no significant difference from LNG through MSP and AI under ICZM. Males more support LNG energy replenishment and energy diversification. Energy deficiency, environmental protection, and economic development were interrelated.

Conclusion The results LPG to LNG revealed less encouraging and implicates many coastal communities in favor of tangible stable electricity without blackout is important than the intangible slogan EBSA protection, or perhaps renewable energy is an alternative approach. An autonomous energy diversification framework through ICZM links Big Data, IoT, Al for sustainable coastal community development (SCCD) indicating no significant difference from gender, environment, age, and is consistent with the goalkeepers' interview results supporting energy diversification. The finding males more support LNG and energy diversification. Finally, the study suggests that legislative enforcement establishment designate expertise teamwork to coordinate administration, integrate programs of energy replenishment, creating an autonomous energy diversification framework for monitoring energy demand, supplies, replenishment, and connect Big Data, loT, Al innovation for SCCD.

\section{Introduction}

The increasing global population surges consumption in energy while land availability is decreasing. Solar, wind, tidal energy has no significant decrease in the demand for oil, gas, coal, and other traditional resources. Energy diversification identifies sources and the possibility of alternative energy to step up the framework. (Dyatlov, Didenko, Ivanova, Soshneva, \& Kulik, 2020). The deployment of offshore facilities in marine renewable energy creates tension as competition for other uses as economic exploitation of 
marine resources increases (Quero García, Chica Ruiz, \& García Sanabria, 2020). Marine spatial planning (MSP) brings together various energy, coastal community, government to coordinate integration how to use marine resources sustainably and provides a mechanism to achieve identification of suitable locations to accommodate energy converters (Galparsoro et al., 2012). Big Data involves storage processing, real-time analysis, the transformation of coastal planning techniques to analyze multiple large volumes of data themes for interactions in environmental and societal elements (Rumson, Hallett, \& Brewer, 2017). A complex relationship requires a multidisciplinary and integrated coastal zone management (ICZM) approach to perform an effective application of management policies directed towards conservation and sustainable exploitation of the coastal zone (Giordano \& Ferraro, 2020). Artificial intelligence (AI) strength converts complex issues and develops remote sensing data into ICZM (Kratzer, Harvey, \& Philipson, 2014) and comprehensive areas balancing environmental, socio-economics, cultural, recreational objectives attempt to achieve sustainability (Khakzad, Pieters, \& Van Balen, 2015). The internet of things (IoT) technology along with Al maybe overcome the challenges of energy use, significantly increases the network complexity and shifts towards renewable energy to eliminate the use of toxic chemicals (Ramadoss, Alam, \& Seeram, 2018). Sustainable Coastal community development (SCCD) preserves natural resources, paying attention to socio-economic and ecosystem protection from economic growth to conservation in the coastal zone. The SCCD discipline incorporated governmental processes, coastal community capacities for appropriate action to counter energy issues of adaptive capacity (Marfai et al., 2008) and suggested MSP implementation (Dunstan et al., 2016). The Convention on Biological Diversity (CBD) agreed in 2008 needs to identify ecologically or biologically significant areas (EBSA) in the world's oceans and focus future conservation management (Dunstan et al., 2016). EBSA covers unique, vulnerability, fragility, slow recovery, rare endemic species, populations, communities and serves important purposes to freely offer varied benefits from the natural environment ecosystem services.

Each energy system harms the environment. Sole energy leads to excessive burdens and causes environmental fatigue. The cost-competitiveness of renewable energy is improved and stored in energy storage technologies for consumption in future needs (Azhgaliyeva, 2019). The current system progressively increases the efficiency of renewable energy generation is considerably impacted by energy framework development (Ortner \& Totschnig, 2019). Energy successful transformation is asserted technically possible, demands fundamental changes, and coordinates efforts to integrate and identify cost-effective solutions to deliver st multiple energy objectives (Gielen et al., 2019). A restart controversial discard plant of coal power and non-nuke energy homeland policy was rejected by referendum in Taiwan on 24 Nov 2018. Although results affecting energy replenishment consequently undermines economic growth, social stability but environmental organizations support these outcomes. A country without an autonomous energy framework leads to national security at risk due to energy is controlled by others. Taiwan has been implementing renewable energy offshore windfarm and paving the way toward autonomous no nuke policy. Simultaneously, the progress of related fields has been developing attributed to intense demands for infrastructure enhancement and broad application. The SCCD has been encountering problems related to environmental protection and economically influential elements (Abu- 
Hijleh \& Jaheen, 2019). Additionally, political struggles usually play a key role in energy policy and seem the most potential risk of no nuke homeland such as the opposite party would resume nuclear energy if won the presidential election on 11/Jan/2020 in Taiwan. The paper suggests activating discard, idle assets, linking current facilities for energy replenishment through MSP connection with Al, loT, Big Data under ICZM to develop energy diversification, simultaneously protect the EBSA for SCCD. Finally, research suggestion creates an autonomous energy diversification framework to stabilize energy supply, mitigating blackout risk from natural disasters or anthropological behavior and promptly offers alternative energy replenishment if energy encounters deficiency in crisis.

\section{Methodology}

The interview coastal community goalkeepers identify whether upgrading current coastal liquefied petroleum gas (LPG) to liquefied natural gas (LNG) for energy replenishment in EBSA under MSP, and autonomous energy diversification through ICZM linking Big Data, loT, Al innovation for SCCD is achievable. Research created the null hypothesis conducting an online sample of data collection and statistical analysis for the test. Finally, the study examined whether these results of the interview and online sampling are consistent or inconsistent.

\subsection{Goalkeepers Interview}

Problem-solving of energy deficiency selected elements of goalkeepers considering capabilities of coordination, negotiation, communication with various organizations in the local district. Additionally, candidate qualifications were required familiar with the community, coastal zone specialty characteristics, expertise, and interest in sustainable development. Code recording consent of goalkeepers was informed and approved by interviewees before performed interviews. The goalkeeper pseudonym John face to face interview energy diversification of economic developments and coastal environment protection was conducted at the regional administrative office about fifty minutes in the afternoon on 22/Dec/2018, and then pseudonym Brown phone interviews about forty minutes in the afternoon on 23/Dec/2018.

\subsection{Data Collection and Analysis}

The preliminary interview outcome was assumed that the coastal community accepted clean energy in EBSA and the results needed to be examined. Therefore, research creating Plan " $A$ " the null hypothesis " Upgrading Current LPG to LNG Develops Economics and Protect EBSA through MSP for Energy Replenishment Is Acceptable " and Plan "B" the null hypothesis " Creating Autonomous Energy Diversification Framework through ICZM Linking Big Data, IoT, Al Innovation for SCCD Is Achievable." The alternative hypothesizes are unacceptable and unachievable respectively. 
An online sampling data collection coastal community, students of National Taiwan Ocean University (NTOU) on 24/Dec, 2018, and a total of 35 respondents were collected for the statistical analysis as experimental justification. Increasing test creditability and reliability, the study used the same null hypothesis to conduct online snowball sampling family members on 17/Dec, 2019 and collected 66 responses to assemble the previous 35 participants $66+35=101$ respondents for the statistical hypothesis test. Sample population widely covered community residents, local district administration, neighbor district citizens, executive graduate students from 3 departments of NTOU; first department, Environmental Biology, and Fisheries Science; second, Institute of Applied English; third Institute of Marine Affairs and Resources Management. These careers of respondents included the elementary, junior high school teacher, teaching assistant, students, professor of NTOU, Coast Guard, Ministry of Transportation, shipping industry, Taiwan Power Company, local Environmental Protection Agent, radio host, police officer, Taiwan Railway Administration, manufacture director, and Fisheries Agency, The Council of Agriculture, one-way ANOVA for the test.

\subsubsection{Plan "A" Upgrading Current LPG to LNG of Economic Development and EBSA Protection through MSP for Energy Replenishment.}

The arguments coal power plant restart and non-nuke energy homeland policy were rejected by referendum in Taiwan on 24 Nov 2018. Creating Plan "A" the null hypothesis " Upgrading Current LPG to LNG Develops Economics and Protect EBSA through MSP for Energy Replenishment is acceptable " for test and the alternative hypothesis is unacceptable. If the government upgrades current coastal LPG to clean energy LNG for energy replenishment of economic development in EBSA under MSP for SCCD. Agree or Disagree.

\subsubsection{Plan "B" established the null hypothesis " Creating Autonomous Energy}

Diversification Framework through ICZM Linking Big Data, IoT, Al Innovation for SCCD Is Achievable." for test and the alternative hypothesis is unachievable.

\section{Results}

Results of preliminary interview suggested activating discard, idle assets to upgrade current LPG to LNG in EBSA for energy replenishment through MSP. Then, connected Big Data, Al, loT under ICZM to develop an energy diversification framework, simultaneously protected environment for SCCD. The null hypothesis test results were not rejected and consistent with the preliminary interview.

\subsection{Interview Goalkeepers}


Preliminary interview results upgrading current LPG to LNG in EBSA through MSP for energy replenishment was acceptable, and establishing an autonomous energy diversification framework through ICZM linking Big Data, IoT, Al innovation for SCCD was supported. Furthermore, finding energy deficiency, environmental protection, and economic development were interrelated.

\subsection{Online Sampling}

The result of 101 responses on 17/Dec/2019 showed no significant difference and was consistent with 35 participation on 24/Dec/2018. Table 1.1 increasing the sample size to upgrade the creditability and reliability of arguments result, research further conducted the same online sampling from members of families for snowball sampling, friends, classmates, colleagues, and 66 respondents were collected on 17/Dec/2019, characteristics including Male 25 (37.88\%), Female 41 (62.12\%); Age 30 Young 45 (68.18\%), 31-50 Middle 6 (9.09\%), 51 Elder 15 (22.73\%); Environment 24 (36.36\%), Non-Environment 42 (63.64\%). These careers covered undergraduate, postgraduate, senior high school students, charity, municipality, retirement, local administration, construction employee, designee employee, labor, business owner, environmental protection agent, and professors.

\subsubsection{Plan "A" Result Was Consistent with Interview}

Results of Plan "A" upgrading current LPG to LNG in EBSA for energy replenishment is acceptable. "Disagree" 42.86\% but "No Comment Total" 34.29\% + "Agree Total" 22.86\% = 57.14\% was consistent with goalkeeper interview results.

\subsubsection{Plan "B" Overwhelmingly Support Energy Diversification Framework}

Table 2 the total 35 participants, Plan “B” energy diversification framework under ICZM linking Big Data, Al, loT innovative for SCCD "Agee" 80.00\%, "No Comment" 20.00\%, and "Disagree" 0\% illustrated overwhelmingly support Plan “B”.

\section{Discussion}

Due to environment and energy generation tradeoff, improved environmental benefits seem to outweigh the deterioration in economic activities such as energy exploitation (Wesseh \& Lin, 2016). Many people claim outcomes of coal power plant restart and non-nuke policy were rejected by referendum in Taiwan, not only affects energy replenishment but also undermines economic development. However, the views were criticized for politicization due to the coal power plant was detrimental but no nuke beneficial for the environment. These distinctive energy policies probably a significant difference. Economic growth and environmental protection were thought traditional trade-off which could be replaced by innovative 
comprehensive integration an alternative such as energy diversification, renewable energy exploitation, Al, and loT application is supported by the previous study Wessh \& Lin, 2016.

Table 1 a total of online 35 respondents characteristics 17 Female (48.57\%), 18 Male (51.43\%); 10 Young (28.57\%), 13 Middle (37.14\%), 12 Elder (34.29\%); 15 Environment (42.86\%), 20 Non-environment (57.14\%) including community resident, neighbor cities citizen, graduate student, elemental, junior high school teacher, professor, Local Administration, Coast Guard, Taiwan Power Company, Environmental Protection Agent and the Council of Agriculture. Table 1.1 primary data of online snowball sampling a total of 66 Respondents on 17/Dec/2019. These participants contained members of families, relatives, classmates, colleagues, career covering undergraduate, postgraduate, senior high school students, charity, local administration, construction employee, designee employee, business owner, environmental protection agent, professors participated in Plan " $A$ " LNG under MSP for energy replenishment and Plan " $\mathrm{B}$ " creating autonomous energy diversification framework through ICZM linking Big Data, IoT, Al Innovation for SCCD.

\subsection{Interview Results Was Supported by Previous Studies}

Pseudonym John and Brown recommended activating a discarded power plant where the place around 500 meters away from current LPG at coastal EBSA under MSP to develop economics and protect EBSA for energy replenishment and was supported by previous studies. Such as MSP attempted to integrate diverse systems, engaging indigenous peoples and local communities (Nai'a Lewis, John Parks, \& Gustavo San Martin, 2017) and offered multi-functionality, integrity, easy use, freely available as an integrated management tool (Pınarbaşı et al., 2017) to focus on achieving specific objectives, related to nationally important strategic priorities, complex, fragmented, and ad hoc emergent processes (Peter J.S. Jones a, 2016). While finding energy deficiency, environmental protection, and economic development are interrelated and attributed to high technology industries' non-stop operation consumed substantial electricity because economic growth required sufficient stable energy supply.

\subsection{LNG Energy Replenishment. The Null Hypothesis Was Not Rejected, Consistent with Interview Result, and Supported by the Previous Studies.}

Supporting cleaner energy LNG for the production of electricity as an alternative approach to increase sustainable production with renewable energy resources (Markopoulos, 2019). LNG tanks deposit and pipeline transportation energy should be approved by the coastal community. A tangible fact of energy deficiency demonstrated great value than an intangible SCCD slogan. Table 2 Plan "A" LNG through MSP for energy replenishment and Plan "B" energy diversification linking Big Data, Al, loT under ICZM for CCSD Total 35 respondents were collected on 24/Dec/2018. Plan "A" "Disagree" $42.86 \%$ but "No Comment Total" 34.29\% + "Agree Total" 22.86\% = 57.14\%. Table 2.1 a total of 101 respondents contain 66 respondents on 17/Dec/2019 and 35 on 24/Dec/2018. The Plan "A" "Disagree Total" declining to 
25.74\% from $42.86 \%$ of Table 2 reflected Plan A LNG in EBSA could be possible for developments. Plan B "Agree Total" $82.18 \%$ is similar to previous research 35 respondents $80.00 \%$ and illustration Plan B is supported.

Table 3 illustration the gender, environment, and age was no significant difference from clean energy exploitation in EBSA for SCCD. Online sampling 35 respondents were collected on 24/Dec/2018. All PValue of Gender group 0.912, Age 0.748, Environment 0.565 were greater than significant interval alpha $0.05 ; \mathrm{F} 0.013,0.304,0.390$ is less than critical value $7.708,5.143,7.708$ respectively. Table 3.1 LNG 35 respondents on 24/Dec/2018 + snowball sampling 66 on 17/Dec/2019 were Total 101. The P-Value of Environment 0.170, Gender 0.361, Age 0.112 were greater than significant interval alpha $0.05, \mathrm{~F} 1.061$, $2.784,3.222$ are less than critical value $7.708,7.708,5.143$ respectively indicating no significant difference and LNG the null hypothesis " Upgrading LPG to LNG Develops Economics and Protect EBSA through MSP for Energy Replenishment is acceptable " was not rejected, consistent with the interview and is supported by previous studies. Such as LNG technology is seen as a factor in decreasing delivery costs, lower capital, operative expenditures and has become a competitive and sustainable option for energy production. It is possible to use re-gasified LNG from any receiving terminal, trading the same resource to prepare for energy production and immediate consumption (Markopoulos, 2019). LNG establishment will conflict with current sectors including fisheries, port, and terminals are been zoning, MSP management approach may reduce the conflicts (Mannan, 2019). MSP a way of easing tensions has not been exploited due to the limitations imposed by legal and administrative barriers (Quero García et al., 2020). Although EBSA was important. However, some citizens prefer tangible energy resources supply with no blackout is important than political slogan intangible sustainable development in EBSA.

\subsubsection{Finding no sufficient evidence is determined as a policy to reject or support LNG in EBSA through MSP for energy replenishment.}

Fig1 "Agree" Male $7 / 18=38.89 \%$ is greater than Female $1 / 17=5.88 \%$."Disagree" Male $8 / 18=44.44 \%$ is greater than Female $7 / 17=41.18 \%$ "No Comment" Male $3 / 18=16.67 \%$ is less than Female $9 / 17=52.94 \%$. The view probably implicated Females less interest in LNG than males causing "Agree" and "No comment" significant difference. The total "Disagree" $42.86 \%$ is less than "Agree" $22.86 \%$ + "No Comment" $34.28 \%$ indicating LPG exploitation in EBSA is acceptable and consistent with interview results. The argument EBSA is important than LNG because of alternative renewable energy such as solar, offshore wind-farm substitutes LNG and protects EBSA which views are supported by previous studies as the following contents of the renewable energy section. Therefore, no sufficient evidence is determined as a policy to reject or support LNG in EBSA for energy replenishment. EBSA is significantly important, however, many citizens assert that stable tangible energy with no blackout demonstrates great value than an intangible political slogan.

\subsubsection{Renewable Energy Is Supported}


Renewable energy is collected from renewable resources, naturally replenished sunlight, wind, rain, tides, waves, and offers energy generation, air, water heating, transportation, rural energy services to play a key role in achieving environmental sustainability (Ike, Usman, Alola, \& Sarkodie, 2020). Probably the coastal community preferred tangible electricity no blackout than intangible political slogan sustainable development or maybe LNG replaced by alternative renewable energy, solar power, offshore wind-farm for energy generation. Nevertheless, the irreversible loss will be incurred in EBSA once the harm happened. Setting criteria for the prioritization of stakeholders incorporate trade-off mechanisms and adapt to new marine renewable energy technologies (Salvador, Gimeno, \& Sanz Larruga, 2019). Offshore energy has been a principal driver for MSP processes, predominantly offshore wind, further expansion of offshore and ocean energy is expected (Yates, 2018). MSP definitively drives marine renewable energy, offshore facilities, compatibility improvement, stakeholders integration, environmental conservation of sensitive areas, and cross-border co-operation (Quero García, García Sanabria, \& Chica Ruiz, 2019). Environmental degradation and habit destruction caused EBSA irreversible loss for decades. Clean or renewable energy generated electricity and protected the environment for SCCD. Renewable biomass photosynthesis was versatile renewable sources and applied for biohydrogen production, aquatic plants, and household effluents. Biohydrogen demonstrates the fermentative conversion of biomass to regain the balance of depleting natural non-renewable resources (Mishra et al., 2019). Renewable energy stable growth mainly fostered by policies, increasing demand played a crucial role in driving global energy transformation and offered a comprehensive perspective development (Wang, Li, Sun, Xu, \& Zhang, 2018).

\subsection{Energy Diversification. The Null Hypothesis Was Not Rejected and Supported by Previous Studies}

Energy discipline involvement politics, commercial, environment affected sustainability, alternative approaches, and production form (Harjanne \& Korhonen, 2019). Energy diversification conveys heavily relying on the sole source that exposes a country vulnerable to disruptions or shocks. Energy-importing countries had few changes in diversification, the extent was taken of political risk (Cohen, Joutz, \& Loungani, 2011). Nuclear waste was asserted detrimental to the environment, ecosystem service, and irreversible harm for the next generation. The deadline year 2025 of non-nuke energy policy in Taiwan is inappropriate due to without enough renewable energy for replenishment, simultaneously, electricity consumption hiking and nuclear energy no consensus. The global energy-environment dynamics are based on the implementation of energy diversification for a global drive towards a cleaner environment and sustainable economic development (Ike et al., 2020).

Table 4 all P-Value at Environment Group 0.774, Gender 0954, Age 0.964 were greater than significant interval alpha 0.05 and $F 0.107,0.004,0.037$ were less than critical value $18.512,18,512,9.552$. Table 4.1 the 35 respondents on $24 / \mathrm{Dec} / 2018+66$ conducting online snowball sampling on $17 / \mathrm{Dec} / 2019=$ total 101 all P-Value of Environment 0.6903 , Gender 0.7924 , Age 0.8478 were greater than significant interval alpha 0.05 and $F 0.183,0.079,0.172$ were less than critical value $7.708,7.708,6.944$ respectively. These indicating no significant difference, and the null hypothesis of energy diversification through ICZM linking 
Big Data, loT, Al innovation for SCCD was not rejected and supported by previous studies. Such as future marine plans must stress on cross-border cooperation. MSP diversity offered alternative approaches in the planning of marine energy uses (Quero García et al., 2019). The ICZM provides economic benefits, healthy coastal ecosystems for reducing vulnerability and innovative approaches for the protection of sustainable investment in coastal communities (Maldonado et al., 2020). The portfolio of energy diversification is asserted essentially for security and alleviate risk. The analysis showed the energy diversification framework through ICZM for SCCD was imperative. ICZM considers the development use and conservation from anthropic pressures on environmental and socio-economic in the coastal zone (Giordano \& Ferraro, 2020). Alternative combinations of resources, technologies, and policies were found capable of attaining future energy pathways to improve energy access, air quality, and security (Gielen et al., 2019).

\subsubsection{Finding Male More Support LNG in EBSA for Energy Replenishment and Energy Diversification for SCCD}

Social-cultural factors advance gender-sensitive policymaking to facilitate the choice of investing in friendly environmental energy solutions (Foudi, Silvestri, Bartek-Lesi, Diallo, \& Csutora, 2019). Fig.1.1 "Agree" Male 22/43=51.16\% is greater than Female 18/58 $=31.03 \%$ indicating Male more support LNG in the EBSA under MSP for energy replenishment as same as Figure 1. Figure 2 autonomous energy diversification framework through ICZM linking Big Data, IoT, Al innovation for SCCD. Total "Agree" 28 (80\%), No Comment 7 (20\%), "Disagree" 0 (0\%), Male 16/18=88.89\% is greater than Female 12/17= 70.59\% indicating more support energy diversification. Figure 2.1 Plan "B" Total "Agree" 83 (82.18\%), “No Comment” 18 (15.84\%), “Disagree” 2 (1.98\%) demonstration overwhelmingly supported. The 35 respondents were collected on 24/Dec/2018 + Online Snowball Sampling 66 on 17/Dec/2019= Total 101. "Agree" Male $37 / 43=86.05 \%$ is greater than Female $46 / 58=79.31 \%$ indicating more support energy diversification is consistent with the previous study. Such as the energy choices may differ from gender ideologies, thus designing energy policies and direct investments suggest considering gender-sensitive as well as social, economical and environmental sustainability (Foudi et al., 2019).

\subsubsection{ICZM Linking Big Data, loT, Al Innovation for SCCD}

Sectoral management coastal zones failed to offer a whole picture of interactions between various uses (Chen, Lee, \& Liu, 2019). ICZM provides conservation, protection, management integrated the mechanistic understanding of marine ecosystem processes with economic tradeoff (Lowerre-Barbieri, Catalán, Frugård Opdal, \& Jørgensen, 2019) and combines the economic, social, environmental aspects to reduce conflict, moreover regulation for all fields affecting the coastal zone, all stakeholders involved (Maldonado et al., 2020). Big data indicated strategy applications in every field and the demand for transcended across all sectors (Rabah, 2018). Al data discipline was revealed by loT offered smart, affordable, reliable, and highly efficient services (Dupont, Cousin, \& Dupont, 2018). loT showed portable, low cost, versatile, and allowed sharing information through the cloud of ICZM for aquaculture farm 
economic improvement and environmental control (Encinas, Ruiz, Cortez, \& Espinoza, 2017). Al, loT delivers socio-economic benefits such as reducing accidents and increasing productivity (Castro \& McLaughlin, 2019). New data technology advances in analytical capacity through Big Data, Al, and social dimensions integration management such as explicit hydrological biological data collection were uploaded to satellite and transferred to data centers for real-time analysis (Lowerre-Barbieri et al., 2019). loT monitoring quality information was useful to identify a possible environmental disaster and how to optimize resources. Al innovation was overwhelmingly supported by gender, environment, and age. Cutting edge IoT combined with Al encounters increasing demand, approach to integrated multi-trophic, and produces environment-friendly (Dupont et al., 2018). Unfortunately, the view an integrated marine framework aims at energy diversification by ICZM linking Big Data, Al, IoT for economic development and environmental protection but lacks administrative coordination, specific legal mechanisms at offering environmental protection against impacts from energy diversification is consistent with the previous study (Salvador et al., 2019).

\section{Conclusion}

The purpose of the paper examines upgrading coastal LPG to LNG for developing economics of energy replenishment in EBSA under MSP environmental protection and an autonomous energy diversification framework through ICZM linking Big Data, IoT, Al for SCCD whether are accepted. The results LPG in situ to LNG revealed less encouraging and implicates many coastal communities in favor of concrete tangible stable electricity without blackout is important than the intangible slogan EBSA protection, or perhaps renewable energy is an alternative approach. Creating an autonomous energy diversification framework through ICZM links Big Data, IoT, Al for SCCD shows no significant difference from gender, environment, age, and is consistent with the goalkeepers' interview results supporting energy diversification. The finding males more support LNG and energy diversification. Finally, the study suggests that legislative enforcement establishment designate expertise teamwork to coordinate administration, integrate programs of energy replenishment, creating an autonomous energy diversification framework for monitoring energy demand, supplies, replenishment and connects Big Data, loT, Al innovation for SCCD.

\section{Author Declaration}

\section{Conflict of Interest}

No conflict of interest exists.

The author confirms that there are no known conflicts of interest associated with this publication and there has been no significant financial support for this work that could have influenced its outcome.

\section{Funding}

No funding was received for this work. 


\section{Intellectual Property}

The author confirms that has given due consideration to the protection of intellectual property associated with this work and that there is no impediments to publication, including the timing of publication, with respect to intellectual property. In so doing we confirm that we have followed the regulations of our institutions concerning intellectual property.

\section{Ethical Approval and Consent to participate}

"Not applicable"

\section{Consent for publication}

“Not applicable"

\section{Availability of supporting data}

"Not applicable"

\section{Authors' contributions}

"Not applicable”

\section{Acknowledgments}

"Not applicable"

\section{Reference}

1. Abu-Hijleh, B., \& Jaheen, N. (2019). Energy and economic impact of the new Dubai municipality green building regulations and potential upgrades of the regulations. Energy Strategy Reviews, 24, 51-67. doi:https://doi.org/10.1016/j.esr.2019.01.004

2. Azhgaliyeva, D. (2019). Energy Storage and Renewable Energy Deployment: Empirical Evidence from OECD countries. Energy Procedia, 158, 3647-3651. doi:https://doi.org/10.1016/j.egypro.2019.01.897

3. Castro, D., \& McLaughlin, M. (2019). Ten Ways the Precautionary Principle Undermines Progress in Artificial Intelligence. Retrieved from

4. Chen, C.-L., Lee, T.-C., \& Liu, C.-H. (2019). Beyond sectoral management: Enhancing Taiwan's coastal management framework through a new dedicated law. Ocean \& Coastal Management, 169, 157-164. 
doi:https://doi.org/10.1016/j.ocecoaman.2018.12.022

5. Cohen, G., Joutz, F., \& Loungani, P. (2011). Measuring energy security: Trends in the diversification of oil and natural gas supplies. Energy Policy, 39(9), 4860-4869.

doi:https://doi.org/10.1016/j.enpol.2011.06.034

6. Dunstan, P. K., Bax, N. J., Dambacher, J. M., Hayes, K. R., Hedge, P. T., Smith, D. C., \& Smith, A. D. (2016). Using ecologically or biologically significant marine areas (EBSAs) to implement marine spatial planning. Ocean \& Coastal Management, 121, 116-127.

7. Dupont, C., Cousin, P., \& Dupont, S. (2018, 4-7 June 2018). IoT for Aquaculture 4.0 Smart and easy-todeploy real-time water monitoring with IoT. Paper presented at the $2018 \mathrm{Global}$ Internet of Things Summit (GloTS).

8. Dyatlov, S., Didenko, N., Ivanova, E., Soshneva, E., \& Kulik, S. (2020). Prospects for Alternative Energy Sources in Global Energy Sector. Paper presented at the IOP Conference Series: Earth and Environmental Science.

9. Encinas, C., Ruiz, E., Cortez, J., \& Espinoza, A. (2017, 26-28 April 2017). Design and implementation of a distributed loT system for the monitoring of water quality in aquaculture. Paper presented at the 2017 Wireless Telecommunications Symposium (WTS).

10. Foudi, S., Silvestri, A., Bartek-Lesi, M., Diallo, A., \& Csutora, M. (2019). D4. 6| Final report on social and cultural factors impacting energy choices and behaviour.

11. Galparsoro, I., Liria, P., Legorburu, I., Bald, J., Chust, G., Ruiz-Minguela, P., . . Borja, Á. (2012). A Marine Spatial Planning Approach to Select Suitable Areas for Installing Wave Energy Converters (WECs), on the Basque Continental Shelf (Bay of Biscay). Coastal Management, 40(1), 1-19. doi:10.1080/08920753.2011.637483

12. Gielen, D., Boshell, F., Saygin, D., Bazilian, M. D., Wagner, N., \& Gorini, R. (2019). The role of renewable energy in the global energy transformation. Energy Strategy Reviews, 24, 38-50. doi:https://doi.org/10.1016/j.esr.2019.01.006

13. Giordano, L., \& Ferraro, L. (2020). Conservation or development? An environmental function analysis assessment of the Volturno River coastal zone (central Tyrrhenian Sea-Italy). Journal of Coastal Conservation, 24(1), 1-12.

14. Harjanne, A., \& Korhonen, J. M. (2019). Abandoning the concept of renewable energy. Energy Policy, 127, 330-340. doi:https://doi.org/10.1016/j.enpol.2018.12.029

15. Ike, G. N., Usman, O., Alola, A. A., \& Sarkodie, S. A. (2020). Environmental quality effects of income, energy prices and trade: The role of renewable energy consumption in G-7 countries. Science of The Total Environment, 721, 137813. doi:https://doi.org/10.1016/j.scitotenv.2020.137813

16. Khakzad, S., Pieters, M., \& Van Balen, K. (2015). Coastal cultural heritage: A resource to be included in integrated coastal zone management. Ocean \& Coastal Management, 118, 110-128.

17. Kratzer, S., Harvey, E. T., \& Philipson, P. (2014). The use of ocean color remote sensing in integrated coastal zone management-A case study from Himmerfjärden, Sweden. Marine Policy, 43, 29-39. 
18. Lowerre-Barbieri, S. K., Catalán, I. A., Frugård Opdal, A., \& Jørgensen, C. (2019). Preparing for the future: integrating spatial ecology into ecosystem-based management. ICES Journal of Marine Science, 76(2), 467-476. doi:10.1093/icesjms/fsy209

19. Maldonado, J. H., Sanchez, M., del Pilar, R., Vargas Morales, M. E., Henao Henao, J. P., Gonzalez Tarazona, Y., .. . Schling, M. (2020). Innovation in economic analysis and evaluation approaches for coastal protection and restoration investments in the Caribbean.

20. Mannan, M. S. (2019). Stakeholder engagement in marine spatial planning of Bangladesh.

21. Marfai, M. A., King, L., Sartohadi, J., Sudrajat, S., Budiani, S. R., \& Yulianto, F. (2008). The impact of tidal flooding on a coastal community in Semarang, Indonesia. The Environmentalist, 28(3), $237-248$. doi:10.1007/s10669-007-9134-4

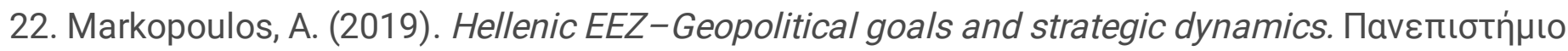
Пвıрaı́́s,

23. Mishra, P., Krishnan, S., Rana, S., Singh, L., Sakinah, M., \& Ab Wahid, Z. (2019). Outlook of fermentative hydrogen production techniques: An overview of dark, photo and integrated dark-photo fermentative approach to biomass. Energy Strategy Reviews, 24, $27-37$.

doi:https://doi.org/10.1016/j.esr.2019.01.001

24. Nai'a Lewis, J. C. D., 'Aulani Wilhelm, Daniel Wagner, Carlos Gaymer,, John Parks, A. F., Susan White, Charles Sheppard, Mark Spalding, \& Gustavo San Martin, A. S., Sue Taei, Tukabu Teroroko and Jacqueline Evans. (2017). Large-Scale Marine Protected Areas:Guidelines for design and management. International Union for Conservation of Nature and Natural Resources, IUCN, Gland, Switzerland.

25. Ortner, A., \& Totschnig, G. (2019). The future relevance of electricity balancing markets in Europe - A 2030 case study. Energy Strategy Reviews, 24, 111-120.

doi:https://doi.org/10.1016/j.esr.2019.01.003

26. Peter J.S. Jones a, n., L.M. Lieberknecht a,1, W. Qiu a,b. (2016). Marine spatial planning in reality: Introduction to case studies and discussion of finding. Marine Policy, 71 (2016) 256-264. doi:10.1016/j.marpol.2016.04.026

27. Pınarbaşı, K., Galparsoro, I., Borja, Á., Stelzenmüller, V., Ehler, C. N., \& Gimpel, A. (2017). Decision support tools in marine spatial planning: Present applications, gaps and future perspectives. Marine Policy, 83, 83-91. doi:10.1016/j.marpol.2017.05.031

28. Quero García, P., Chica Ruiz, J. A., \& García Sanabria, J. (2020). Blue energy and marine spatial planning in Southern Europe. Energy Policy, 140, 111421.

doi:https://doi.org/10.1016/j.enpol.2020.111421

29. Quero García, P., García Sanabria, J., \& Chica Ruiz, J. A. (2019). The role of maritime spatial planning on the advance of blue energy in the European Union. Marine Policy, 99, 123-131. doi:https://doi.org/10.1016/j.marpol.2018.10.015

30. Rabah, K. (2018). Convergence of Al, IoT, big data and blockchain: a review. The Lake Institute Journal, 1(1), 1-18. 
31. Ramadoss, T. S., Alam, H., \& Seeram, P. (2018). Artificial Intelligence and Internet of Things enabled Circular economy. The International Journal of Engineering and Science, DOI, 10, 1813-0709035563.

32. Rumson, A. G., Hallett, S. H., \& Brewer, T. R. (2017). Coastal risk adaptation: the potential role of accessible geospatial Big Data. Marine Policy, 83, 100-110.

doi:https://doi.org/10.1016/j.marpol.2017.05.032

33. Salvador, S., Gimeno, L., \& Sanz Larruga, F. J. (2019). The influence of maritime spatial planning on the development of marine renewable energies in Portugal and Spain: Legal challenges and opportunities. Energy Policy, 128, 316-328. doi:https://doi.org/10.1016/j.enpol.2018.12.066

34. Wang, X., Li, N., Sun, W., Xu, S., \& Zhang, Z. (2018). Quantitative analysis of distributed and centralized development of renewable energy. Global Energy Interconnection, 1(5), 576-584. doi:https://doi.org/10.14171/j.2096-5117.gei.2018.05.007

35. Wesseh, P. K., \& Lin, B. (2016). Modeling environmental policy with and without abatement substitution: A tradeoff between economics and environment? Applied Energy, 167, 34-43. doi:https://doi.org/10.1016/j.apenergy.2016.01.031

36. Yates, K. E., Bradshaw, C. (Ed.). (2018). Offshore Energy and Marine Spatial Planning. Taylor \& Francis Group an informa business, Offshore Energy and Marine Spatial Planning. London: Routledge.

\section{Tables}

Table 1 Primary data of descriptive statistics a total of online 35 respondents conducting on 24/Dec/2018 included community resident, neighbor cities citizen, graduate student, elemental, junior high school teacher, professor, Local Administration, Coast Guard, Taiwan Power Company, Environmental Protection Agent and the Council of Agriculture in Plan " $A$ " the null hypothesis "Upgrading Current liquefied petroleum gas (LPG) to liquefied natural gas (LNG) Develops Economics and Protect ecologically biologically significant area (EBSA) through marine spatial planning (MSP) for Energy Replenishment is acceptable " and Plan " $\mathrm{B}$ " " Creating Autonomous Energy Diversification Framework through integrated coastal zone management (ICZM) Linking Big Data, internet of things (IoT), artificial intelligence (Al) Innovation for sustainable coastal community development (SCCD) Is Achievable." 


\begin{tabular}{|c|c|c|c|c|c|c|c|}
\hline \multicolumn{2}{|c|}{ 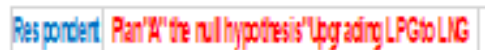 } & \multirow{3}{*}{ 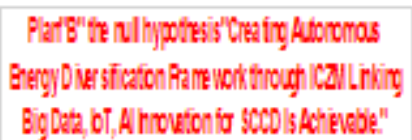 } & \multirow[b]{3}{*}{ Gerk: } & \multirow[b]{3}{*}{ larimg } & \multirow[b]{3}{*}{$A g$ Gap } & \multirow[b]{3}{*}{ Carm } & \multirow{3}{*}{ 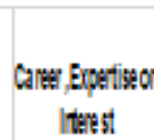 } \\
\hline on & 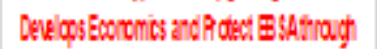 & & & & & & \\
\hline 240002018 & 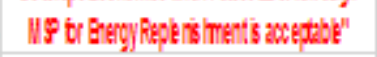 & & & & & & \\
\hline 1 & locominatit & Agew & V & 160 & W Young & Eknential Shool Teshe & Norsivounat \\
\hline 2 & Nocomment & Agen & F & No & * Woung & 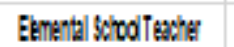 & Norstriomet \\
\hline 3 & Nocomment: & Arw & $F$ & $Y_{e s}$ & 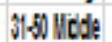 & 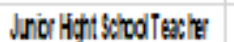 & Nor-8viomet \\
\hline 4 & Agen & Agth & $F$ & $\mathbb{N o}$ & 314ECE & Lotalkmiritation & Nonstivounat \\
\hline$j$ & Nocomment & Agen & $F$ & Yes & 31/30 Wedt: & Lotal keministaton & Norsturomet \\
\hline 6 & Dixgen & Age & $F$ & Yess & ริ|\$) Wdde & Latal|Aminitation & Nor:svioumet \\
\hline 1 & Agu & Age & V & No & W Young & Latal|kminstaton & Nor:sviounet \\
\hline 8 & Divgen & Age & F & No & 31/30 Widde & Latalexirititaion & Nor:sivounat \\
\hline 9 & Nocomment & Nocomment & F & No & 31/30 Wdde & Latal|kinistaton & Norstuounet \\
\hline 10 & Nocoment: & Nocoment: & F & Yes & 31 EEk & Latal|Aminstaion & Nor:bvoumet \\
\hline 11 & Dispen & Ages & F & $\gamma_{e s}$ & 31/30 Wdde & Lxal|keministaion & Norsviounat \\
\hline 12 & Nocomment & Nocomment & F & $\mathbb{N o}$ & W Young & Gadatis Sutent & Nonstivounat \\
\hline 13 & Nocomnent & Nocomment & F & No & W Young & Godatis Sulvint & Nor-8vioumat \\
\hline 14 & Nocoment & Nocomnent & V & $\gamma_{\varphi s}$ & $31+\mathrm{Edg}$ & 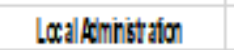 & Nor-suvomat \\
\hline 15 & Disgye & locomment & F & $\mathbb{N o}$ & W Young & Tactix Astistat & Evioment \\
\hline 16 & Agen & Agu & V & Yes & (3) (\$) Widde & cosichard & Eviomant \\
\hline 17 & Dixgen & Agte & V & $Y_{e s}$ & 31 EEck & Protesog & Eviomant \\
\hline 18 & Disgen & Age & $F$ & $\mathrm{No}$ & W Young & Temcix Assistat & Evioment \\
\hline 19 & Disgente & Age & V & Yes & 3ิ|⿰㇒) Wide & cosichad & Evioment \\
\hline 20 & Agen & Age & V & 16 & (3) & cosistgat & Norsivoumet \\
\hline 21 & Nocomment & Aqu & $F$ & No & 3ิ|⿰㇒) Wide & Winstyofflansootion & Evioment \\
\hline 2 & Disgen & Age & V & 16 & 3ิ|⿰亻) Widde & Shixnghasty & Nor:sivounat \\
\hline 2 & Disgen & Age & $F$ & Yes & 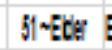 & Envơme tal protecion Aget & t Evioment \\
\hline$y$ & Ague & Agtu & V & $\mathrm{No}$ & W Young & Gadatid Sutent & Evioment \\
\hline 25 & Disgen & Age & V & $\gamma_{a s}$ & $51+\mathrm{Edg}$ & Talian Poine Compary & Nor:suroumet \\
\hline x & Agen & Age & V & Yes & 31 Ekts & cosistond & Evioment \\
\hline 27 & Nocomment & Age & V & Yes & 31 Eteg & Radiolost & Norsviounat \\
\hline x & Disgente & Age & VI & $Y_{e s}$ & 31/30 Widde & Poin Ofix: & Evioment \\
\hline 20 & Dixgen & Age & $F$ & $\mathrm{No}$ & 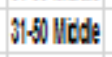 & Eknental Shool Tence & Nor-sivoumat \\
\hline 11 & Agu & Aga & U & Yes & 31 EEk & Poessog & Eviomant \\
\hline วิ1 & Disgente & Age & U & Yes & 51 Eter & Próessog & Evioment \\
\hline 3 & Nocotment: & Age & F & No & $51 \times E$ Ege & Talian Raaliay Aministrion & Evioment \\
\hline$M$ & Disgente & Nocomentit & V & No & W Young & comnuty/ricet & Norstivomat \\
\hline 4 & Diggen & Age & V & $Y_{a s}$ & $31+$ Edeg & Ua uatre Diector & Evioment \\
\hline 管 & Agen & Age & V & $Y_{e s}$ & W Young & Counciofitgicitise & Evioment \\
\hline
\end{tabular}

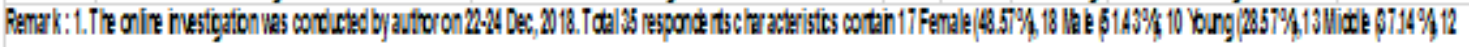

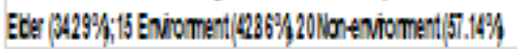

Table 1.1 Primary Data of Online Snowball Sampling a Total of 66 Respondents on 17/Dec/2019. These participants contained members of families, relatives, classmates, colleagues, career covering undergraduate, postgraduate, senior high school students, charity, local administration, construction employee, designee employee, business owner, environmental protection agent, professors participated in Plan "A" LNG under MSP and Plan "B" creating autonomous energy diversification framework through ICZM linking Big Data, IoT, Al Innovation for SCCD. 


\begin{tabular}{|c|c|c|c|c|c|c|c|}
\hline $\begin{array}{c}\text { Raspondart } \\
\text { on } \\
1710002019\end{array}$ & 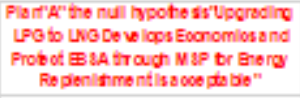 & 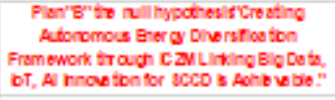 & cender & Morisge & $\mathrm{AgF}$ & $\begin{array}{l}\text { Bxpetas or } \\
\text { Interst }\end{array}$ & Carie: \\
\hline 1 & Dlaspere & Agere & Fente & ves & 31-50 Mode & Non-Envonn rent & Local Adninibiration \\
\hline 2 & No Conment & No Comment & Forve & No & 51 ader & Non-Envonnent & Chatt/ \\
\hline 3 & Agree & Agree & Mose & Ves & 5t ace & Enionment & Munidepalt/ \\
\hline 4 & No Conment & Agret & Fende & ves & S1 ade & Envonnent & Environnentas Acent \\
\hline 5 & Agres & Aget & Fetret & ves & 51 ace & Non-Envonnent & Conctuction Enplo yet \\
\hline 6 & Agete & Agete & Mote & Ves & 51 ade & Envonnent & Corctuction Employet \\
\hline 7 & Agret & Agret & Mse & Ves & S1 ace & Non-Envonirent & Locd Adrinibtation \\
\hline 8 & Dlasper & Agret & Fente & No & 31-50 Mid de & Non-Envoron rent & Local Adrinibtration \\
\hline 9 & Agres & Agres & Mose & ves & S1 Eder & Non-Envon rent & Retienent \\
\hline 10 & Agret & Agree & Mse & No & $\sim 30$ Young & Endonment & Uni vezity Sudent \\
\hline 11 & Agret & Agret & Mote & ves & $51 \sim$ ade & Non-Envoronirent & Fetientent \\
\hline 12 & Dlasget & Agret & Mse & Ves & 51 ace & Envonnent & Potezoor \\
\hline 13 & Agret & Agret & Fente & No & 51 ade & Non-Envoron rent & Desi gret Enployet \\
\hline 14 & Agret & Agret & Ferret & Ves & 31-50 Mid de & Envonment & Environnentas Acent \\
\hline 15 & No Conment & Agret & Forre & No & $\sim 30$ Young & Non-Envonnrent & Uni vesht/ Sudent \\
\hline 16 & Aget: & Alete & Mse & Ves & $51 \sim$ ade & Envonnent & Buaress Oure \\
\hline 17 & Aget & Agres & Mse & No & $\sim 30$ Young & Envontent & Univezity Sudent \\
\hline 18 & Agret & No Comment & Mate & No & $\sim 30$ Young & Non-Envoron rent & Uni vezity Sudent \\
\hline 19 & No Comment & Agete & Fetrie & No & $\sim 30$ Young & Envonnent & Uni vez:t/ Sudent \\
\hline 20 & Dlasget & Agete & Ferve & No & $\sim 30$ Young & Non-Envoron rent: & Univezit/ Sudent \\
\hline 21 & No Comment & No Comment & Fente & No & $\sim 30$ Young & Non-Envonnent & Univezit/ Sudent \\
\hline$\approx$ & Dlsaget & Aget & Fente & No & $\sim 30$ Young & Envonent & Unilozily Sudent \\
\hline 23 & No Comment & Alote & Fente & No & $\sim 30$ Young & Non-Envron rent & Univezly Sudent \\
\hline 24 & No Comment & Agret & Fente & $y=$ & 31-50 Mode & Non-Envonnrent & Locd Administaton \\
\hline 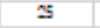 & Disget & Agret & Fetrie & No & $\sim 30$ Young & Envonnent & Undegrouated suden: \\
\hline $\mathbf{s}$ & Disager & Alote & Mse & No & $\sim 30$ Youno & Non-Envon rent & Univezit/ Sudent \\
\hline 27 & Agres & Aores & Fente & No & 31-50 Mid de & Non-Envorn rent & Buainess Ore \\
\hline 23 & No Comment & Agret & Mose & No & $\sim 30$ Young & Envonnent & Uni vezity Sudent \\
\hline 2 & No Comment & Agret & Fente & No & $\sim 30$ Young & Enionent & Uni vez:t/ Sudeent \\
\hline 30 & No Conment & Aget: & Mose & No & $\sim 30$ Young & Envonnent & Undegrouated sident: \\
\hline 31 & Agret & Agret & Ferret & ves & 51 Ecer & Non-Ghron rent & Losbour \\
\hline 2 & Dlasper & Agree & Moe & No & $\sim 30$ Young & Enionent: & Unlez:t/ Student \\
\hline 33 & Agret & Agret & Fente & No & $51 \sim$ ade & Non-Envonn rent & Fetivenent \\
\hline 34 & No Comment & Agret & Mote & No & $\sim 30$ Young & Enionent & Uni vez:t/ Sudeent \\
\hline 25 & No Comment & Agret & Ferre & No & $\sim 30$ Young & Envonent & Holdech od Sudent \\
\hline 36 & No Comment & Aget & Moe & No & $\sim 30$ Young & Non-Envorn rent & Unlezit/ Sudent \\
\hline 37 & No Comment & Agres & Mse & No & $\sim 30$ Young & Envonment & Undergobuated Strident \\
\hline 33 & Dlsaget & No Conment & Fente & yes & 51 ade: & Envonnent & Retienent \\
\hline 29 & No Conment & Agres & Mse & No & $\sim 30$ Young & Non-Envonnent: & Un lezily Sudent \\
\hline 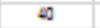 & Agret & Agret & Fertet & $\mathrm{No}$ & $\sim 30$ Young & Non-Envoron rent & Uni vez:t/ Sudent \\
\hline 41 & No Comment & Agres & Fetrie & $\mathrm{No}$ & $\sim 30$ Young & Non-Envoron rent & Uni vesity Sudent \\
\hline 2 & Agres & Agere & Fente & No & $\sim 30$ Young & Non-Envorn rent & Uni vesity Sudent \\
\hline$a$ & No Comment & Aoret & Mote & No & $\sim 30$ Young & Non-Envoronnent & Uni vezily Sudent \\
\hline 4 & No Comment & No Comment & Ferve & No & $\sim 30$ Young & Non-Gnvonnent & Uni vez:t/ Sudent \\
\hline 55 & No Comment & Agret & Fente & No & $\sim 30$ Young & Non-Envoron rent & Uni vezity Sudent \\
\hline 5 & Agret & Disagest & Mate & No & $\sim 30$ Yourg & Envioment & 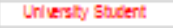 \\
\hline 67 & No conment & Dlasgret & Fente & No & $\sim 30$ Yourg & Mon-Envionne nt & Uni verihy Sactent \\
\hline a & No Comment & Agres & Fetre & No & $\sim 30$ Young & Non-Envonnent & Uni vezit/ Sudent \\
\hline 29 & Agese & No Comment & Mote & No & $\sim 30$ Young & Non-Envorn rent & Uni vez:t/ Sudent \\
\hline 50 & Arete & Agres & Ferret & No & $\sim 30$ Young & Non-Emvonnent & Uni westy Sudent \\
\hline 51 & No Conment & Agete & Fende & No & $\sim 30$ Young & Non-Envonn rent & Univest/ sudent \\
\hline 52 & Agere & Aget & Mse & No & $\sim 30$ Young & Non-Gnvonnent & Uni ves:t/ Sudent \\
\hline 53 & Agret & Agres & Fente & No & $\sim 30$ Young & Non-Envonnent & Unl vezilt/ Shodent \\
\hline 54 & No Comment & Aget & Fente & No & $\sim 30$ Young & Non-Envonnent & Uni vez:t/ Sudent \\
\hline 55 & No Comment & No Comment & Fente & No & $\sim 30$ Young & Non-Envonnent & Univesit/ Sudent \\
\hline 56 & Dlsoget & Agere & Fente & No & $\sim 30$ Young & Non-Envonn rent & Uni ves:t/ Sudent \\
\hline 57 & Agret & Agret & Ferre & No & $\sim 30$ Young & Envonont & Hildect ool Sudent \\
\hline 58 & Agret & No Conment & Ferret & No & 31-50 Modie & Non-Envoron rent & Enteprete Enploy et \\
\hline 59 & No Comment & Alote & Fenve & No & $\sim 30$ Young & Mon-Envoron rent & Uni lezit/ Stident \\
\hline 60 & Agret & Agret & Fente & No & $\sim 30$ Young & Non-Envonnent & Un lezity Sudent \\
\hline 61 & No Comment & Agret & Ferret & No & $\sim 30$ Young & Endonment & Unl vesity Sudent \\
\hline 62 & Agres & No Comment & Mote & No & $\sim 30$ Young & Non-Envoronrent: & Uni vezity Sudent \\
\hline 63 & Agret & No Comment & Mse & No & $\sim 30$ Young & Envonent & Uni lozit/ Sudent \\
\hline 64 & Agres & Aget & Mse & ves & $51 \sim$ ade & Non-Envonnent & Retienent \\
\hline 65 & No Comment & No Conment & Fente & No & $\sim 30$ Young & Non-Envonn rent: & Un lez:t/ sudent \\
\hline 65 & Dissget & Agete & Fente & No & $\sim 30$ Young & Envonent & Un loshty Sudent \\
\hline
\end{tabular}

Table 2: Plan "A" LNG through MSP in EBSA for energy replenishment and Plan "B" energy diversification linking Al, IoT under ICZM for SCCD total of 35 respondents were collected on 24/Dec/2018. Plan A "Disagree" 42.86\% but "No Comment Total" 34.29\% + "Agree Total" 22.86\% = 57.14\% was consistent with interview results upgrading current LPG to LNG in EBSA for energy replenishment. Plan B "Agee" 80.00\%, "No Comment" 20.00\%, and "Disagree" 0\% illustrated overwhelmingly support. 


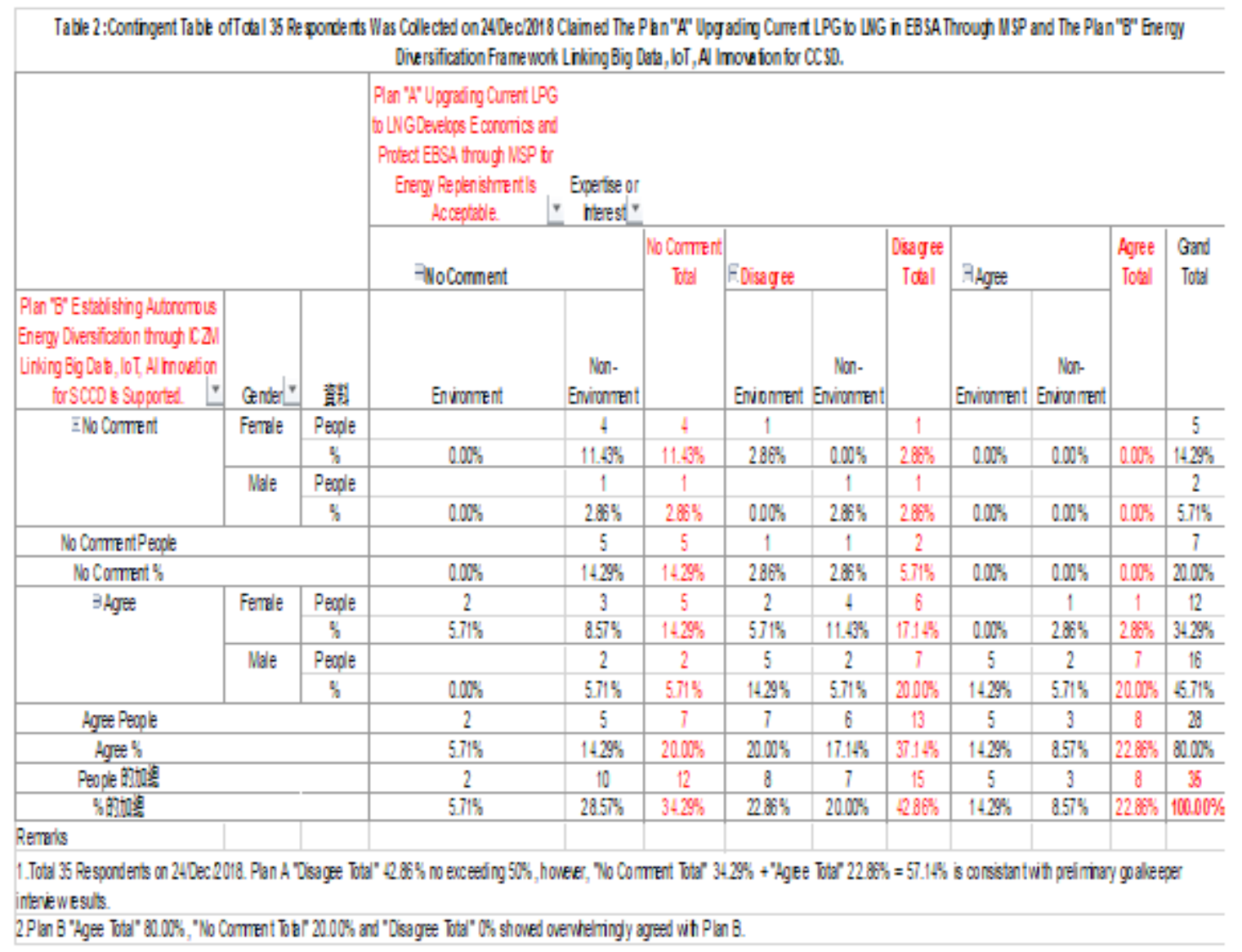

Table 2.1 Total of 101 Respondents contains 66 respondents on 17/Dec/2019 and 35 on 24/Dec/2018. The Plan " $A$ " LNG energy replenishment through MSP and the Plan " $B$ " energy diversification framework linking Big Data, Al, loT under ICZM for SCCD. "Disagree Total" declining to $25.74 \%$ from $42.86 \%$ of Table 2 reflected Plan A LNG in EBSA could be possible for developments. 


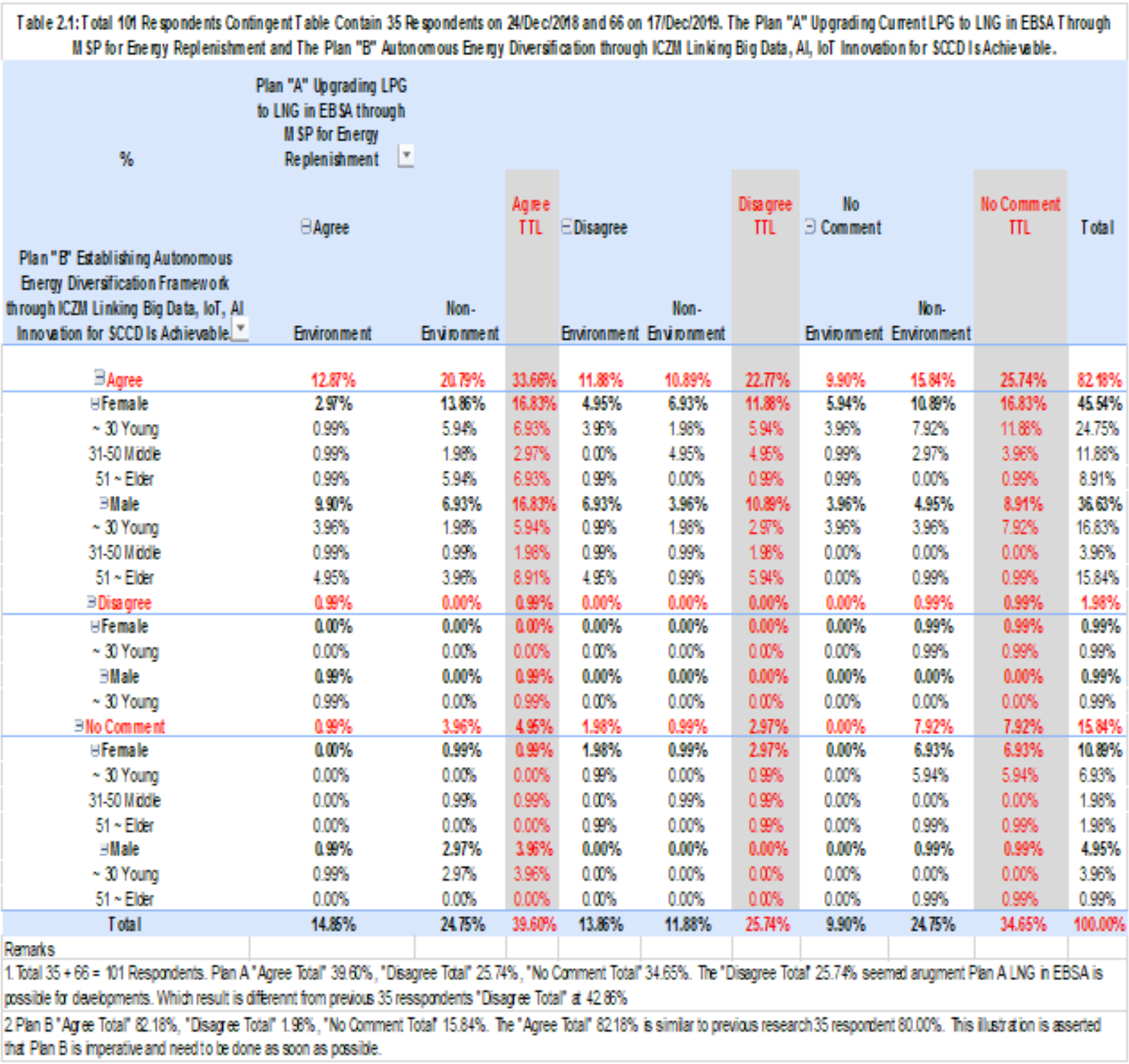

Table 3 Plan "A" all P-Value of Gender group 0.912, Age 0.748, Environment 0.565 were greater than significant interval alpha 0.05 indicating no significant difference. The null hypothesis " Upgrading LPG to LNG Develops Economics and Protect EBSA through MSP for Energy Replenishment is acceptable " was not rejected and consistent with goalkeeper interview results. Although EBSA was important. However, some citizens preferred tangible energy resources supply with no blackout important than political slogan intangible sustainable development in EBSA. 
Table 3.1. Previous Respondents 35 on 24 Dec $2017+$ Online Snowball Sam pling $66=$ total 101 Respondents Were Conducted on 17/Ded2019. The Summ ary of Study Plan "A" Upgrading LPG to LNG in BSA under MSP for Energy Replenisment.

\begin{tabular}{|c|c|c|c|c|c|c|}
\hline Group & Number & Sum & Mean & Variance & & \\
\hline Female & 3 & 58 & 19.33333333 & 26.3333 & & \\
\hline Male & 3 & 43 & 14.33333333 & 44.3333 & & \\
\hline Environment & 3 & 39 & 13 & 7 & & \\
\hline Non-Enwionment & 3 & 62 & 20.600000007 & 50.3333 & & \\
\hline$\sim 30$ Young & 3 & 55 & 18.33333333 & 72.3333 & & \\
\hline 31-50 Middle & 3 & 18 & 6 & 1 & & \\
\hline $51 \sim$ Elder & 3 & 28 & 9.333333333 & 37.3333 & & \\
\hline \multicolumn{7}{|l|}{ OneWay ANOVA } \\
\hline Source & SS & Degree of Freedom & MS & $\mathrm{F}$ & P-Value & Critical Value \\
\hline Between (Female, Male) & 37.5 & 1 & 37.5 & 1.06132 & 0.301129 & 7.708617122 \\
\hline Within (Female, Male) & 111.3333333 & 1 & 35.333333333 & & & \\
\hline Total & 178.8333333 & 5 & & & & \\
\hline Between (Enuroonment, Non-Ervironment) & 88.160000007 & 1 & 88.160600007 & $278 / 21$ & 0.170522 & 7.708617122 \\
\hline Within (Envionment, Non-Envionment) & 126.60000067 & 1 & 31.600000007 & & & \\
\hline Total & 211.8333333 & 5 & & & & \\
\hline Between (Young, Middle, Elder) & 211.202022 & 2 & 1221111111 & 3.22287 & 0.112015 & 5.11325285 \\
\hline Within (Young, Middle, Elder) & 227.3333333 & 6 & 37.88888889 & & & \\
\hline Total & 171.5555556 & 8 & & & & \\
\hline \multicolumn{7}{|l|}{ Remarks } \\
\hline 1.Male "Mean" 11.333 smaller than Female & howerer, "Ve & $" 11.333$ larger the & 26.333 indicater & much di & as ive fo & $\operatorname{Plan} \mathrm{A}$. \\
\hline
\end{tabular}

Table 4 The Summary and ANOVA of Plan "B" the null hypothesis "Creating Autonomous Energy Diversification Framework through ICZM Linking Big Data, IoT, Al Innovation for SCCD Is Achievable". All P-Value at Environment Group 0.774, Gender 0954, Age 0.964 were larger than significant interval alpha $0.05 ; \mathrm{F} 0.107,0.004,0.037$ were less than critical value $18.512,18,512,9.552$ indicating no significant difference, and the null hypothesis was not rejected. 
Table 4.1. Previous Respondents 35 Was Collected on $24 / D e c / 2018$ + Online Snowball Sampling 66 Collected on 17/ Dec/2019 = Total 101 Respondents. The Summary of Study Plan "B" Establishing Autonomous Energy Diversification through ICZM Linking Big Data, IOT, AI Innovation for SCCD Is Supported.

\begin{tabular}{|c|c|c|c|c|c|c|}
\hline Group & Number & Sum & Mean & Variance & & \\
\hline Environment & 3 & 39 & 13 & 364 & & \\
\hline NonEnvironment & 3 & 62 & 20.66666667 & 596.33333 & & \\
\hline Female & 3 & 58 & 19.33333333 & 558.33333 & & \\
\hline Male & 3 & 43 & 14.33333333 & 389.33333 & & \\
\hline$\sim 30$ Young & 3 & 55 & 18.33333333 & 440.33333 & & \\
\hline $31.50 \mathrm{M}$ iddle & 2 & 18 & 9 & 98 & & \\
\hline $51 \sim$ Elder & 2 & 28 & 14 & 242 & & \\
\hline \multicolumn{7}{|l|}{ One-Way ANOVA } \\
\hline Source & SS & Degree of Freedom & MS & $\mathrm{F}$ & P-Value & Critical Value \\
\hline Between (Environment Group) & 88.166666667 & 1 & 88.16666667 & 0.1836168 & 0.69035 & 7.708647422 \\
\hline Within (Environment Group) & 1920.6666667 & 4 & 480.1666667 & & & \\
\hline Total (E nuironment Group) & 2008.833333 & 5 & & & & \\
\hline Between (Gender Group) & 37.5 & $\overline{1}$ & 37.5 & 0.0791418 & 0.792417 & 7.708647422 \\
\hline Within (Gender Group) & 1895.333333 & 4 & 473.8333333 & & & \\
\hline Total (Gender Group) & 1932.833333 & 5 & & & & \\
\hline Between (Age Group) & 105.047619 & 2 & 52.52380952 & 0.1721152 & 0.847802 & 6.94427191 \\
\hline Within (Age Group) & 1220.6666667 & 4 & 305.1666667 & & & \\
\hline Total (Age Group) & 1325.714286 & 6 & & & & \\
\hline \multicolumn{7}{|l|}{ Remarks } \\
\hline \multicolumn{7}{|c|}{ 1. Non-E nuronment "Vaiance" 596.33 indicates the most diverse oppinion from Plan B } \\
\hline \multicolumn{3}{|c|}{ 3. Youg 30 "Vaiance" 440.33 larger than E Ider 242 and 31.50 Middle 98 is the relative small illustrate no diversion fror } & \multicolumn{4}{|c|}{ 2.Female "Vaiance" 558.33 larger than Male 389.33 shows diversion fom Plan B } \\
\hline
\end{tabular}

\section{Figures}


Fig 1. Online Sampling Total 35 Respondent about Plan "A" Upgrading Current LPG to LNG in EBSA under MSP for Energy Replenishment. "No Comment" 12 (34.28\%), "Disagree" 15 (42.86\%), "Agree" 8 (22.86\%) Were Collected on 24/Dec/2018

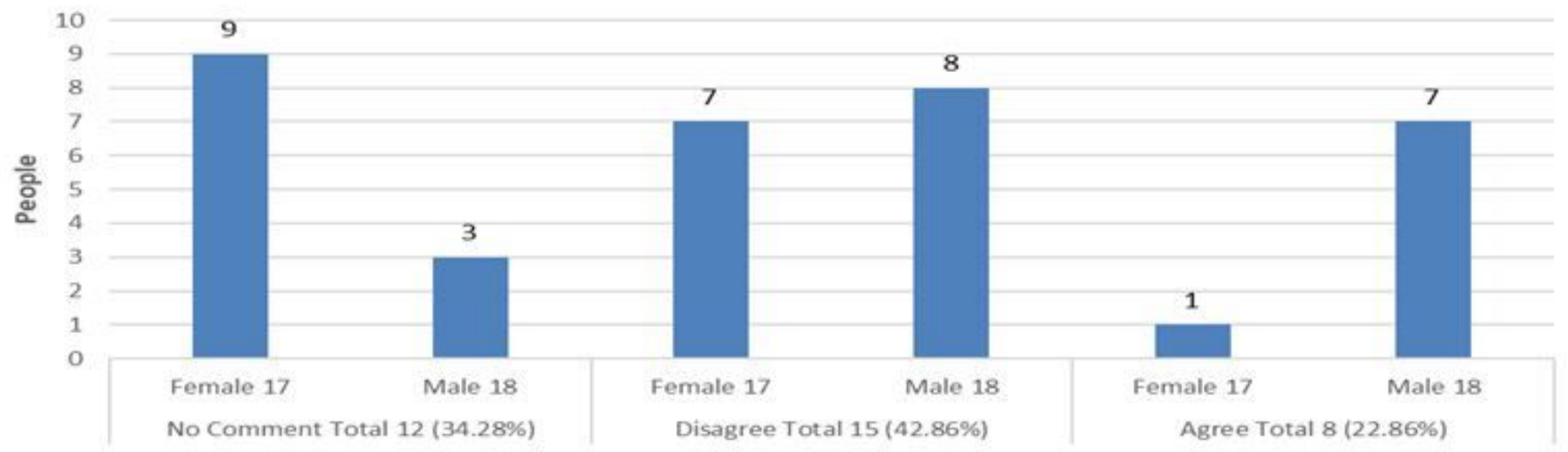

Total 35 online respondents characteristics contained Female 17 (48.57\%), Male 18 (51.43\%);

Environment $15(42.86 \%)$, Non Environment 20 (57.14\%); 30 Young 10 (28.57\%), 31-50 Middle $13(37.14 \%)$, 51 Elder $12(34.29 \%)$

Plan ALNG - Gender

\section{Figure 1}

Plan "A" upgraded current coastal liquified petroleum gas (LPG) to clean energy liquefied natural gas (LNG) in the ecological or biological significant area (EBSA) under marine spatial planning (MSP) for energy replenishment. "Agree" Male $7 / 18=38.89 \%$ is greater than Female 1/17=5.88\%."Disagree" Male $8 / 18=44.44 \%$ is greater than Female $7 / 17=41.18 \%$ "No Comment" Male $3 / 18=16.67 \%$ is less than Female 9/17= 52.94\%. The total "Disagree" $42.86 \%$ is less than "Agree" $22.86 \%$ + "No Comment" $34.28 \%$ indicating LPG exploitation in EBSA is acceptable and consistent with interview results. No sufficient evidence to determine a policy of reject or support Plan "A" LNG in EBSA for energy replenishment. Although EBSA is significantly important. However, many citizens asserted that stable tangible electricity with no blackout demonstrated great value than an intangible political slogan in EBSA. 


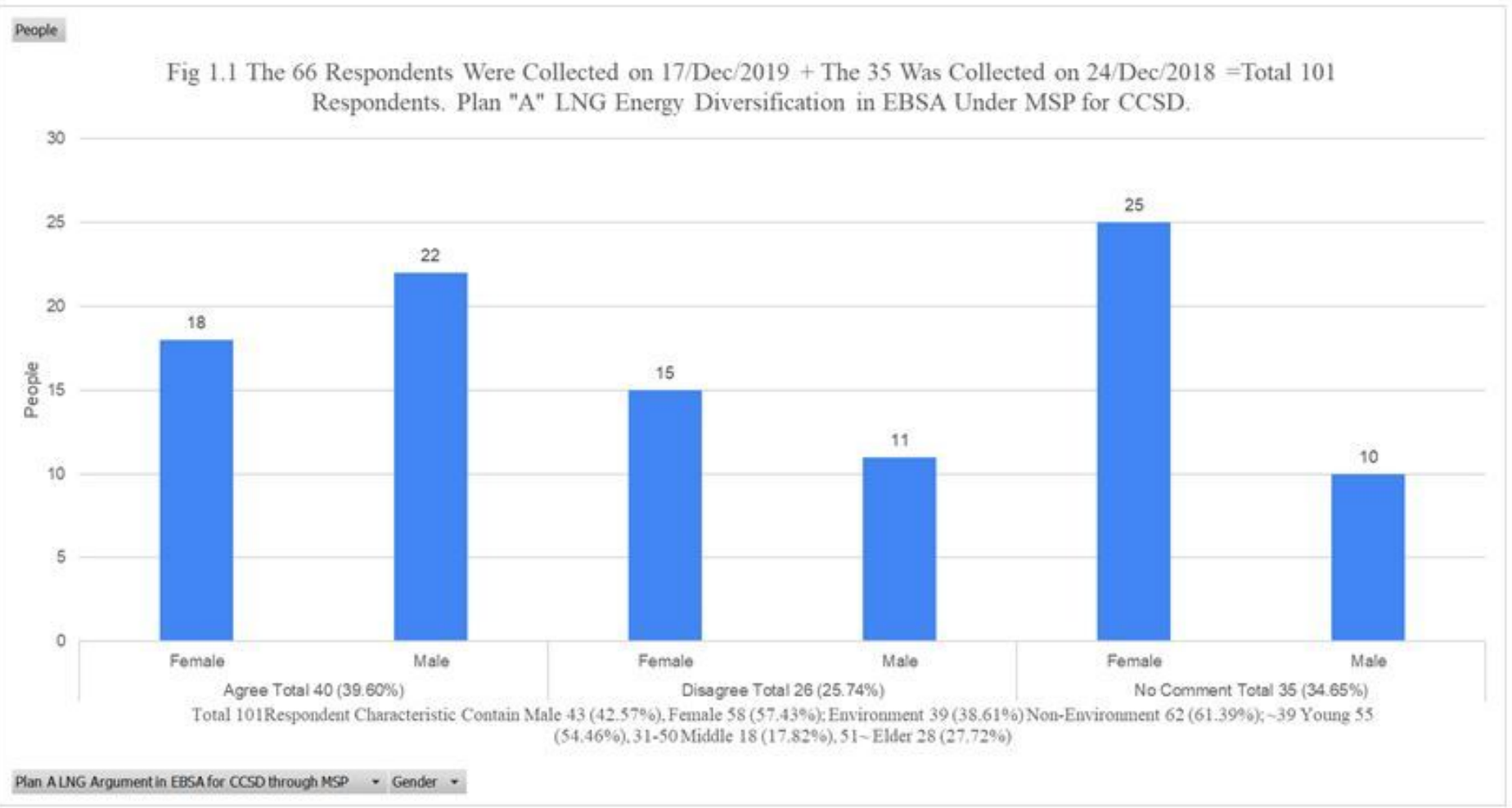

\section{Figure 2}

1.1 Plan "A" investigation LNG in the EBSA under MSP for Energy Replenishment. Indicating Male more support than Female as same as Figure 1."Agree" Male 22/43=51.16\% is greater than Femal 18/58 $=31.03 \%$ "Disagree" Male 11/43= 25.58\% is less than female 15/58= 25.86\% "No Comment" Male 10/43 $=23.26 \%$ is less than Female $25 / 58=43.10 \%$

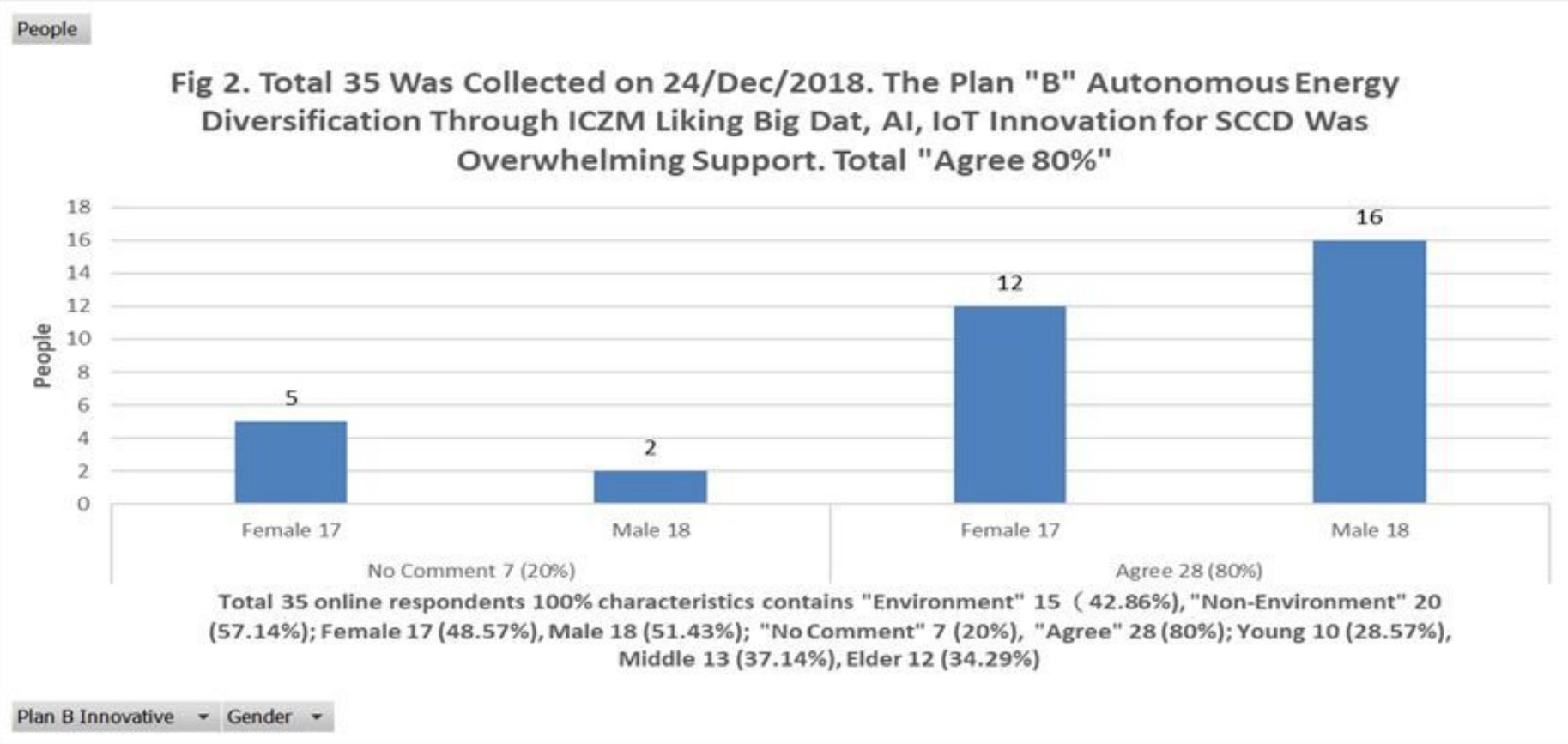




\section{Figure 3}

Plan " $\mathrm{B}$ " creating autonomous energy diversification framework through integrated coastal zone management (ICZM) linking Big Data, internet of things (IoT), artificial intelligence (Al) Innovation for sustainable coastal community development (SCCD) is achievable. Total "Agree" 28 (80\%), No Comment 7 (20\%), "Disagree" 0 (0\%), Male 16/18=88.89\% is greater than Female 12/17= 70.59\% "No Comment" Male $2 / 18=11.11 \%$ is less than Female $5 / 17=29.41 \%$. Indicating Male more support energy diversification than Female.

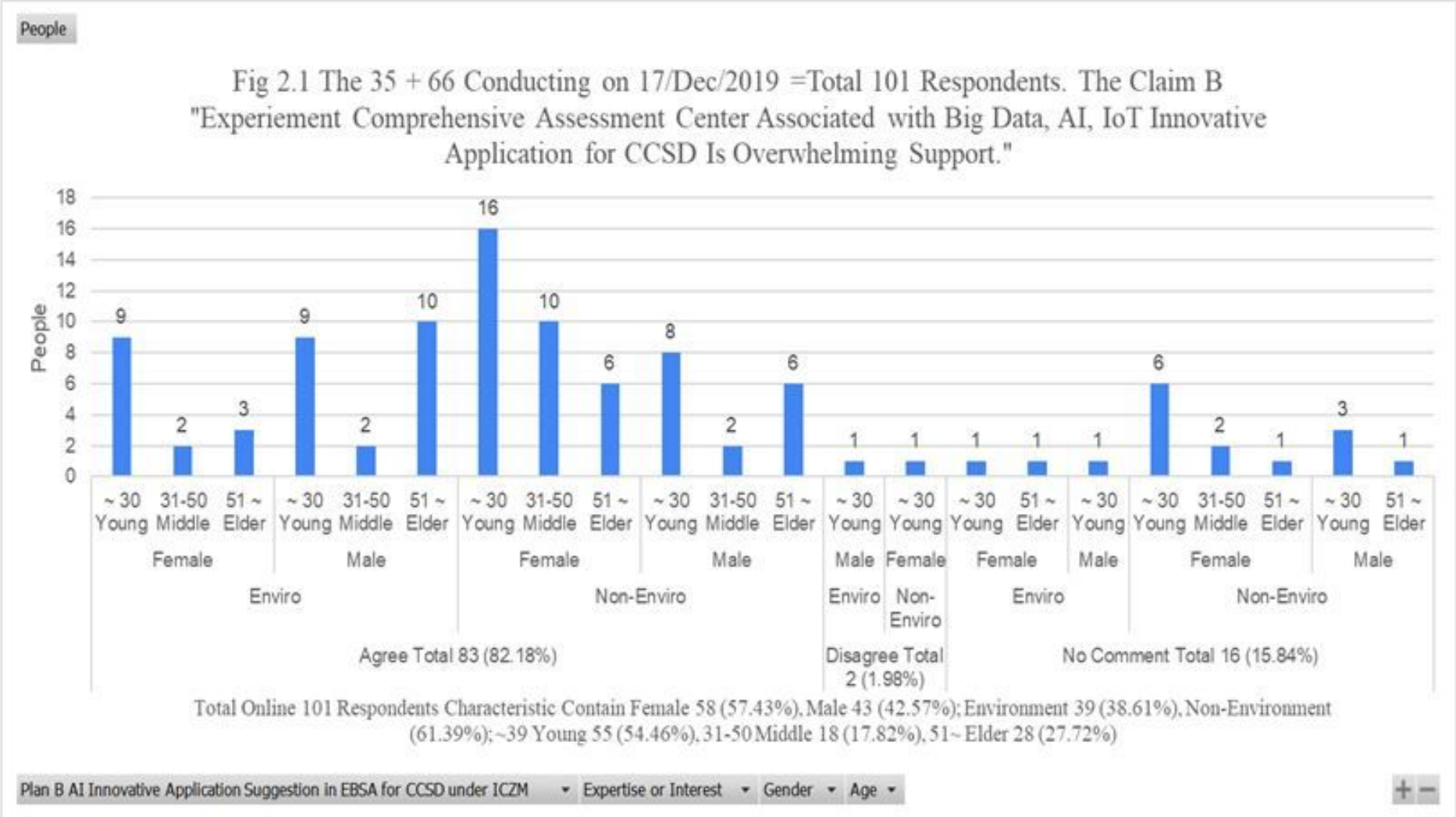

\section{Figure 4}

2.1 "Plan "B" creating autonomous energy diversification framework through ICZM linking Big Data, loT, Al innovation for SCCD illustrated "Agree Total" 83 (82.18\%), "No Comment Total 18 (15.84\%), "Disagree Total 2 (1.98\%) demonstration Overwhelmingly Supported. The 35 Respondents Was Conducted on 24/Dec/2018 + Online Snowball Sampling 66 on 17/Dec/2019 = Total 101. The Noticeable 16 figure Showed the majority of " 30 Young", "Female”, “Non-Environment”. According to Fig 2, Plan B, The 35 respondents, agreed total $28 / 35=80 \%$, female total $12 / 35=34.29 \%$, male total $16 / 35=45.71 \%$. But, Fig 2.1, The 101 respondents, agreed a total $83(82.18 \%)$, Female total $14+32=46 / 101=45.54 \%$ was larger than Male $21+16=37 / 101=36.63 \%$. 